Ekspansi: Jurnal Ekonomi, Keuangan, Perbankan dan Akuntansi

ISSN (Online): 2580-7668 ISSN (Print): 2085-5230

Vol. 11, No. 1 (May 2019), Page. 13 - 22

\title{
THE INITIAL IMPLEMENTATION OF ACCRUAL BASED ACCOUNTING, THE EFFECT ON PERFORMANCE AND FINANCIAL REPORTING QUALITY AT LOCAL GOVERNMENTS IN INDONESIA
}

\author{
Rindu Rika Gamayuni ${ }^{1}$ \\ ${ }^{1}$ Accounting Department, Economic and Business Faculty, University of Lampung, Bandar \\ Lampung, Indonesia \\ Corresponding Email: rindu.gamayuni@yahoo.com
}

\begin{abstract}
In Indonesia local government, accrual based Government Accounting Standard (GAS) was started to be mandatorily applied in 2015, so this research aims to investigate to what extent the role of accrual GAS implementation toward quality of financial reporting and financial performance especially at local governments. Population of this study is Local Governments of districts/cities in Indonesia for Fiscal Year 2014 and Fiscal Year 2015, as many as 542 local governments (before and after the implementation of accrual base). Sampling method uses probability sampling which is cluster sampling. In this case, the population is divided based on 34 province clusters, so the number of sample obtained is 242 local governments of districts/cities in Indonesia. The hypothesis testing uses paired t test. The object of research is the financial reporting quality and financial performance. The results of this study provide empirical evidence that there is an increase in the quality of financial reporting after the application of accrual-based accounting at local governments in Indonesia, but have not proven the existence of the increased financial performance. There is no differences in financial performance before and after accrual based accounting implementation at local governments in Indonesia. This hyphothesis was not supported due to the application of accrual basis accounting is still in the early stages of implementation (1 year) that still have constraints in limited human resources competencies, necessary adaptations or adjustments in the process of change. Local governments in Indonesia must apply accrual based accounting because it is proven that it increases financial report quality. However, the system implementation in the beginning period found many obstacles so it needs continuous adjustment and learning in order to reach desirable goal. There is still a debate on how important is the implementation or adoption of accrual IPSAS in many countries, including Indonesia. In Indonesia, the implementation of accrual based Government Accounting Standard (SAP/GAS) is new mandatory since 2015. The result of this research will give contribution to the theory, that there is significant influence of implementation accrual based GAS to financial reporting quality, but no significant increase in financial performance (efficiency and effectiveness) at local government. Therefore, this result study will be used to determine related policies about the implementation of accrual based GAS.
\end{abstract}

Keywords: Accrual Based Accounting, Financial Reporting Quality, Financial Performance, Government

DOI: $10.35313 /$ ekspansi.v11i1.1326

Article History:

Received: 20 - 11 - 2018

Revised: $7-12-2018$

Accepted: $4-1-2019$ 


\section{INTRODUCTION}

New Public Management (NPM) is the existence of reformation in financial information system, that is an important element in improving management and decision making at government agencies (Guthrie et al., 1999). Reformation of financial information system is marked by the used of accrual based accounting in public sector, that previously used traditional cash accounting system (Lapsley, 1999). This reformation is marked by the adoption of IPSAS (International Public Sector Accounting Standard) that is a standard of accrual based public sector accounting. The reformation of financial information has occurred in many countries in the world including Indonesia. In Indonesia, the implementation of accrual based Government Accounting Standard (SAP/GAS) is based on Peraturan Pemerintah Nomor 71 Tahun 2010 (replacing PP Nomor 24 Tahun 2005). Accrual based GAS is aimed to give better advantage to stakeholders, both users and government financial report examiner.

However, there is still a debate on how important is the implementation or adoption of accrual IPSAS in many countries. The adoptions of IPSAS among others are the ones that have been occurring in European Union countries, Greece, Spain, Australia, and Romania. Those countries have some reasons underlying the adoption of IPSAS in their countries. Those reasons are because the importance of accrual based accounting to improve the quality of financial report, better state financial management for central governments and regional governments, and other reason which is isomorphism approach (IPSAS implementation to obtain institutional legitimacy). In Indonesia, accrual based GAS was started to be mandatorily applied in 2015 , so this research aims to investigate to what extent the role of accrual GAS implementation toward quality of financial reporting and financial performance especially at local governments.

As explained in NPM, The trend changing into accrual accounting is caused by the presence of needs on transparency and efficiency (Christiaens, Reyniers, Role, 2010). at the change of accounting standard base from cash based to accrual based is in order to increase effectiveness, efficiency, and transparency of public service providing. The change of accrual accounting is an important element in NPM because the modernization in public management (especially government) needs useful financial information, and this need can be fulfilled by accrual accounting (Christiaens, Reyniers, Role, 2010).

The difficulty in accrual accounting standard implementation is faced by public sector in Romania that obstructs the success of public sector policy reformation in Rumania (Ilie dan Miose, 2012). Some accounting activities in public sector do not give the real concition of asset, finance, and earnings. It complicates accounting system evaluation process. Public management gives the base for effective process of public administration supervising and controlling. IPSAS that is an accrual based accounting standard can help public management to increase the quality of financial information, to help internal controlling and supervising from a public institution, and to increase the value of financial information (Ilie and Miose, 2012). A study in Malta State Government (one of countries in Europe Union Countries) disclosed that IPSAS 
cannot fully be applied as government accounting policy and is not entirely effective to fulfil the needs of public sector, IPSAS still needs adjustment in its application (Jones and Caruana, 2015). However, vice versa, the condition occurring in Australia based on the study done by McPhee (2012), accrual accounting and budgeting have given significant contribution for administration in public sector. It is imposible to solve accounting problems in public sector in a short period of time, and expecting the system that runs well in short period of time, but there are quite many improvements so far (McPhee, 2012). Generally, the result of performance examination at local governments in Indonesia concluded the activity implementation on the object of examination has not been fully effective (IHPS BPK-RI, 2016). Based on the phenomena and theories described previously, so the study aims to search empirical evidence on the effect of accrual based GAS on financial reporting quality and financial performance at local governments in Indonesia.

\section{LITERATURE REVIEW}

\subsection{Application of Accrual Based Government Accounting Standard (GAS)}

Laughlin (2012) defined accrual accounting is transaction recording method that not only is done when cash is received or payment with cash, but the income acceptance and payment that are deferred that will be received and paid with cash that in the future can be recorded and should be recorded. Accrual based of GAS started to be mandatorily applied as accounting standard in Indoneian governments in 2015. Financial report is based on PP Nomor 71 TAhun 2010 (Accrual based GAS) consisting of: Report on Budget Outcomes (LRA), Operational Report (LO), Laporan Perubahan Saldo Anggaran Lebih / Excess Budget Balance Report (LPSAL), Equity Changes Report (LPE), and Cash Flow Report (LAK) for the year ended on that date, and Notes on Financial Report (CaLK).

\subsection{Financial Reporting Quality}

The purpose of financial reporting by entity of public sector is to provide information about the entity that is useful for the financial reporting users, for IPSAS responsibility and decision making purpose (2010). Qualified financial reporting is financial reporting resulting useful information for its users, which is information meeting information qualitative characteristics or qualified financial information characteristics (IPSAS, 2010; Belkaoui, 2004). PP No. 71 tahun 2010 about Government Accounting Standard that has adjusted to International Public Sector Accounting Standards (IPSAS) (2010), mentions that the purpose of government financial reporting is to present useful information for users in evaluating accountability and decision making of economic, social, and political decisions. Dimensions of qualified financial reporting based on the Government Accounting Standards (GAS) (2010) are as the following: (1) Relevant, (2) Reliable, (3) Can be compared, and (4) Can be understood. 


\subsection{Local Government Financial Performance}

In public sector, an activity is said to be effective if the activity is able to provide community service that is the target determined previously. Effectiveness ratio illustrates the ability of local governments in realizing planned regional revenue (PAD) compared to the target determined based on regional real potential. The bigger PAD realization compared to PAD target, it can be said more effective. Efficiency ratio is the ratio describing the comparison between output (expense realization) and input (regional revenue realization). An activity is said has been conducted efficiently if the implementation of the job has reached output with the lowest cost (input) or with minimum cost, the desirable result is obtained. The smaller ratio, the more efficient. In this case, by asumming that expenditure expense is in accordance with its designation and meeting what has been planned.

\subsection{The Effect of Accrual Based Government Accounting Standards (GAS) on Financial Reporting Quality at District/City Governments in Indonesia}

The use of accrual accounting in public sector can increase comparability of financial performance and give better public resources responsibility and more transparent financial data (Christiaens, Reyniers, Role, 2010). Comparability and transparency are dimensions of financial reporting quality. Indonesian governments apply accrual accounting base because it has advantages which are giving full illustration on government financial position, presenting real information (reliable) on rights and responsibility of government, useful in evaluating government performance related to service cost, efficiency, and objective achievement (Ministry of Finance, 2014). Reliable financial information is a dimension of financial reporting quality.

The result of study done by Galera and Bolivar (2012) stated that accrual based accounting standard application by the Governments of Spain has increased the quality of financial information/report, through the increase of transparency, accountability, and efficiency of public servicw. In line with Ball (2015) disclosing the adoption of IPSAS that is international standard of accrual based public sector accounting by the Governments of Greece, it results more qualified financial report because it is as the base of analysis that will prevent incorrect decision making. Similarly, Grossi and Soverchia (2011) stated that there has been accounting reformation in Europe Union Countries through the adoption of accrual based IPSAS which is the application of accrual accounting in financial reporting, and the importance of financial report analysis based on accrual accounting system to increase accountability or financial responsibility to stakeholder.

In Indonesia, the result of study done by Simanjuntak (2010) stated that in the period before reformation (before the use of accrual based accounting), accounting system had not been able to increase accountability of government bureaucracy performance in giving public services to community, output resulted by government accounting in Indonesia is often inaccurate, late, and uninformative, so it cannot be reliable in decision making. Financial reporting quality of local governments generally are illustrated from the opinion given by Supreme Audit Agency (SAA). The opinion 
is a professional statement as a conclusion of examiner on the fairness level of information presented in financial report. SAA opinion can be the benchmark (indicator) for evaluating financial reporting quality of a government entity. Based on the theory and the results of the previous studies, hypothesis that is formulated is as the following:

$\mathrm{H}_{1}$ : There is an increase of financial reporting quality after the implementation of accrual based government accounting standard.

\subsection{The Effect of Accrual Based Government Accounting Standard (GAS) Implementation on Financial Performance (Efficiency and Effectiveness) at District/City Government in Indonesia}

In the last decade, public sector has borrowed the technique used in private sector to increase efficacy (effectiveness), efficiency, and transparency on public services (Gomez, Hernandez, Bastida, 2015). Public management is defined as the use of quantitative indicator to obtain result and efficiency from public program, quality, and effectiveness for its users (Hatry, 1999). The implementation of public management system as mentioned in many study, can simplify budgeting process, finding organization aspect that has not been efficient, and increasing public sector management (Gomez, Hernandez, Bastida, 2015).

The result of study done by McPhee (2006) in Australia, it disclosed that accrual based accounting and budgeting can help management to understand better and manage program in an organization. Accounting policy related to earnings and cost disclosure, asset and obligation management, for example changes in determining asset value and obligation caused by depreciation and revaluation, can give important information to management. The result of study from McPhee (2006) in Australian governments stated that many practitioners obtain advantage from accrual based budgeting and reporting, among others are program management more efficiently and effectively. The study by The Organisation for Economic Co-operation and Development (OECD) stated that the advantages of accrual accounting in public sector are: (1) giving the base for accountability and flexibility for public sector manager, (2) facilitating resources management in order to be more efficient and effective, (3) focusing more on government and decision management.

With accrual based reporting, the user can identify financial position of government and its changes, how the government funds its activity in accordance with its funding ability so that government program management becomes more efficient and effective. Cash based accounting gives little information related to obligation and asset potential in the future, and accrual accounting is more suitable in planning, financial managing, and decision making (Christiaens, Reyniers, Role, 2010). Based on the theory and the results of previous studies, hypothesis is stated as the following: $\mathrm{H}_{2 \mathrm{a}}$ : There is an increase of financial performance (effectiveness ratio) after the implementation of accrual based GAS.

$\mathrm{H}_{2 b}$ : There is an increase of efficiency after the implementation of accrual based GAS. 


\section{RESEARCH METHOD}

Population of this study is Local Governments of districts/cities in Indonesia for Fiscal Year 2014 (before the implementation of accrual base) and Fiscal Year 2015 (after the implementation of accrual base), as many as 542 local governments. Sampling method uses probability sampling which is cluster sampling. In this case, the population is divided based on 34 province clusters, so the number of sample obtained is 242 local governments of districts/cities in Indonesia. The hypothesis testing uses paired $t$ test. Data are sourced from Financial Reports of Local Governments of Districts/Cities in Indonesia and data of BPK -RI opinion on Financial Reports of Local Governments of Districts/Cities in Indonesia.

Table 1. Variables in Research and Indicators

\begin{tabular}{|l|l|}
\hline Variable & \multicolumn{1}{|c|}{ Indicator } \\
\hline 1. Financial Reporting & $\begin{array}{l}\text { Opinion of SAA Audit on Local Government } \\
\text { Financial Report } \\
\text { 1. Reasonable without exception (WTP) } \\
\text { 2. Reasonable without exception with } \\
\text { explanation (WTP DPP) }\end{array}$ \\
& $\begin{array}{l}\text { 3. Reasonable with exception (WDP) } \\
\text { 4. Unreasonable opinion (adverse) }\end{array}$ \\
& 5. Statement not giving opinion (disclaimer)
\end{tabular}

\section{RESULT AND DISCUSSION}

Table 2. Analysis Statistic Result

\begin{tabular}{|c|c|c|c|}
\hline Variable & Mean & $\begin{array}{l}\text { Probability } \\
\text { (Significance) }\end{array}$ & Hypothesis Result \\
\hline FSQ 1 (Before) & 3.76 & \multirow[t]{2}{*}{0.000} & \multirow{2}{*}{$\begin{array}{l}\text { Supported, financial reporting significantly } \\
\text { increases after accrual base implementation. }\end{array}$} \\
\hline FSQ 2 (After) & 4.13 & & \\
\hline Effectivity1 (Before) & 1.02 & \multirow[t]{2}{*}{0.000} & \multirow{2}{*}{$\begin{array}{l}\text { Not supported, effectiveness ratio significantly } \\
\text { decreases after accrual base implementation. }\end{array}$} \\
\hline Effectivity2 (After) & 0.97 & & \\
\hline Efficiency1 (B & 0.96 & \multirow[t]{2}{*}{0.361} & \multirow{2}{*}{$\begin{array}{l}\text { Not supported, there is no significantly increase } \\
\text { of efficiency after accrual base implementation. }\end{array}$} \\
\hline Efficiency2 (After) & 0.97 & & \\
\hline
\end{tabular}




\subsection{The Effect of Accrual Based Government Accounting Standard (GAS) on Financial Reporting Quality at Local Government in Indonesia}

The result of Wilcoxon non-parametric difference test shows that there is an increase of financial reporting quality significantly (significance level less than 0.05). The increase of financial reporting quality increases from the mean of 3.76 (before accrual GAS implementation) to 4.13 (after accrual GAS implementation). It proves that the use of accrual accounting in public sector can give better public resources responsibility and more realiable financial data (Christiaens, Reyniers, Role, 2010). The implementation of accrual accounting base in Indonesia is useful in presenting reasonable information about rights and responsibility of government, is useful in evaluating government performance related to service cost, efficiency, and goal achievement. The success of accrual based GAS implementation is in accordance with the result of studies done by Galera and Bolivar (2012) and Ball (2015), Grossi and Soverchia (2011) in Europe Union Countries.

\subsection{The Effect of Accrual Based Government Accounting Standard (GAS) Implementation on Financial Performance (Efficiency and Effectiveness) at Local Government in Indonesia}

Based on Wilcoxon non-parametric statistics test, it proves that there is significant difference on financial performance which is effectiveness ratio at local government in Indonesia. There is significant decrease on effectiveness ratio from the mean of 1.02 (before accrual base implementation) to 0.97 (after accrual base implementation). The ratio value of effectiveness is 1.02 meaning that financial performance of local governments in Indonesia averagely has been effective because the effectiveness ration is above $100 \%$. The revenue realization of local governments from local real income is $102 \%$, compared to its revenue target. One year after accrual base implementation, effectiveness ratio is having a decrease to 0.97. Although having a decrease, effectiveness value after accrual base implementation still can be categorized effective. As well as the result of Wilcoxon statistics test, it gives evidence that there is no significant difference in efficiency ratio. Efficiency ratio increases from 0.96 (before accrual base implementation) to 0.97 (after accrual base implementation), but it is not significant. Efficiency value 90\% - 100\% includes in category inefficient (Budiarto, 2007). The smaller efficiency ratio value shows more efficient performance. Efficiency value is 0.96 , meaning that expense realization is $96 \%$ from regional revenue realization. Some areas still have efficiency ratio above $100 \%$ meaning that the expense of local government still exceeds it revenue. Local government has not been able to allocate existing budgeting to be used efficiently or economically as well as not able to increase public services.

The result of this study cannot give supporting evidence on the theory stating that there is an increase in financial performance (efficient and effective) after accrual base implementation, as Gomez, Hernandez, Bastida (2015) explaining that public management system implementation can simplify budgeting process, find organization aspects that have been efficient, increase efficiency and efficacy (effectiveness) of public 
sector management. Next, it does not support OECD statement that the advantage of accrual accounting that is helpful for public sector can facilitate resources management to be more efficient and effective. The result of this study is not in line with the result study done by McPhee (2006) in Australian government, where the advantage from accrual based budgeting and reporting, for example managing program to be more efficient and effective. Unsupported hypotheses 2 and 3 are caused by accrual base Accounting Standard implementation at government in Indonesia that is still in the initial stage of implementation. The implementation of a new system is having obstacles in human resources competition, and needs adaptation or adjustment in changing process from cash based system to accrual based.

\section{CONCLUSION}

The results of this study are:

a. Financial reporting quality increases significantly after accrual based accounting implementation at local governments in Indonesia, meaning that the theory is supported that accrual based accounting is important to increase financial reporting quality.

b. Financial performance (effectiveness) decreases significantly after accrual based accounting implementation at local governments in Indonesia. The hyphothesis 2 is not supported. But however, the financial performance after that implementation is still in category effective.

c. There is no siginificant increase in financial performance (efficiency) after accrual based accounting implementation. The theory is not supported because accrual based accounting implementation is still in the beginning period of implementation (1 year) that is still in adjusting and learning stage.

\section{REFERENCES}

Badan Pemeriksa Keuangan(BPK-RI). 2016. Ikhtisar Hasil Pemeriksaan Semester 2 Tahun 2016. Jakarta.

Ball, I. 2015. Debate: Would IPSAS help Greece? Public Money and Management, 35(6), 397-398. Http://doi.org/10.1080/09540962.2015.10769

Belkaoui, Ahmed Riahi. 2004. Accounting Theory. Fifth Edition. Published by Thomson Learning.

Beest, Ferdy van., Geert Braam, Suzanne Boelens. 2009. Quality of Financial Reporting: measuring qualitative characteristics. Nijmegen Center for Economics (NiCE), Institute for Management Research, Radboud University Nijmegen, The Netherlands. http://www.ru.nl/nice/workingpapers

Budiarto, Bambang. 2007. Pemgukuran Keberhasilan Pengelolaan Keuangan Daerah. Seminar Ekonomi Daerah. Surabaya.

Christiaens, J., Reyniers, B., \& Rolle, C. 2010. Impact of IPSAS on reforming governmental financial information systems: a comparative study. International 
Review of Administrative Sciences, 76(3), 537-554. https://doi.org/10.1177/0020852310372449

Christiaens, J., Vanhee, C., Manes-Rossi, F., Aversano, N., \& Cauwenberge, P. van. 2014. The effect of IPSAS on reforming governmental financial reporting: an international comparison. International Review of Administrative Sciences, 81(1), 158-177. https://doi.org/10.1177/0020852314546580

Galera, A. N., \& Bolivar, M. P. R. 2012. Adopting IPSAS to improve governmental accountability in Spain : an empirical study. Int. J. Critical Accounting, 4(5/6), $572-$ 607.

Guthrie J, Olson O and Humphrey C. 1999. Debating developments in new public financial management: The limits of global theorising and some new ways forward. Financial Accountability $\mathcal{E}$ Management 15(3-4): 209-228.

Halim, Abdul. 2007. Akuntansi Sektor Publik Akuntansi Keuangan Daerah. Edisi Ke-3. Jakarta: Salemba Empat.

Hatry, H.P. 1999. Performance Measurement: Getting Results. Washington, DC: Urban Institute.

Ilie, E., \& Miose, N.-M. 2012. IPSAS and the application of these standards in the Romania. Procedia Social and Behavioral Sciences, 62, 35-39. https://doi.org/10.1016/j.sbspro.2012.09.008

Jones, R., \& Caruana, J. 2015. Governmental accounting in Malta towards IPSAS within the context of the European Union. International Review of Administrative Science, 0(0), 1-18.

International Public Sector Accounting Standard (IPSAS). 2010. The International Public Sector Accounting Standard Board (IPSASB). https://www.iasplus.com/en/standards/ipsas

Lapsley I. 1999. Accounting and the New Public Management: Instruments of substantive efficiency or a rationalising modernity. Financial Accountability \& Management 15(3-4): 201-207.

Laughlin R and Pallot J. 1998. Trends, patterns and influencing factors: Some reflections. In: Olson O, Guthrie J and Humphrey C (eds) Global Warning: Debating International Developments in New Public Financial Management. Oslo, Norway: Cappelen Akademisk Forlang.

Meigs, Walter B., Meigs, Robert F. 2000. Financial Accounting. Eight Edition. Mc GrawHill Inc.

Mcphee, I. 2006. Financial Management in the Public Sector How accrual accounting enhances governance and accountability. CPA Australia Public Sector Finance and Management Conference Financial, (August).

Peraturan Pemerintah Nomor 270/PMK.05/2014 tentang Penerapan Standar Akuntansi Pemerintah Berbasis Akrual pada Pemrintah Pusat.

Peraturan Pemerintah Nomor 71 Tahun 2010 tentang Standar Akuntansi Pemerintah. Simanjuntak, Binsar H. 2010. Penerapan Akuntansi Berbasis Akrual di Sektor Pemerintahan di Indonesia. Kongres XI Ikatan Akuntan Indonesia, Jakarta 9 Desember 2010. 
Zafra-Gomez, J. L., Lopez-Hernandez, a. M., \& Hernandez-Bastida, a. 2009. Evaluating financial performance in local government: maximizing the benchmarking value. International Review of Administrative Sciences, 75(1), 151-167. https://doi.org/10.1177/0020852308099510 